\title{
Technology in Social Entrepreneurship Studies: A Bibliometric Analysis (1990-2019)
}

\author{
Angela Dettori ${ }^{1} \&$ Michela Floris $^{1}$ \\ ${ }^{1}$ Department of Economics and Business, University of Cagliari, Cagliari, Italy \\ Correspondence: Angela Dettori, Department of Economics and Business, University of Cagliari, Via \\ Sant'Ignazio 74, 09123 - Cagliari, Italy. E-mail: angela.dettori@unica.it
}

Received: December 14, 2020

Accepted: January 10, 2021

Online Published: February 5, 2021

doi:10.5539/ijbm.v16n3p41

URL: https://doi.org/10.5539/ijbm.v16n3p41

\begin{abstract}
This paper presents a bibliometric analysis of the academic studies focused on technology in social entrepreneurship, published from 1990 to 2019 and indexed in WoS database. Quantitative evidence supports the idea that this topic has gained increasing attention of scholars, especially recently. However, there are rooms for further studies oriented to analyse social enterprises' ability to adopt technologies to be sustainable and competitive in a hyper-turbulent market in which technology represents a key component. The descriptive statistical analysis identifies the most prolific authors, journals, countries and institutions that have contributed to the development of this topic; and the citation trends reveal a significant consolidation of this field of research that reflects the development of other theories regarding the role that technology has in social entrepreneurship.
\end{abstract}

Keywords: technology, social entrepreneurship, bibliometric analysis

\section{Introduction}

A growing body of literature has recently developed around social entrepreneurship and social enterprise concepts (Chell, Nicolopoulou, \& Karatas-Ozkan, 2010; Rawhouser, Cummings, \& Newbert, 2019; Shaw \& de Bruin, 2013). This increasing scholarly attention would seem to suggest that social entrepreneurship is of considerable interest both for the fascinating aspect of the business model (Ashraf, Razzaque, Liaw, Ray, \& Hasan, 2019), and for its mission (Muñoz \& Kimmitt, 2019) and goals (Yin \& Chen, 2019). More in detail, the importance of social entrepreneurship roots on its ability to create social value and social development, also in terms of wealth and job creation (Ana Maria Peredo \& McLean, 2006; Ana María Peredo, McLean, \& Tremblay, 2019), and on its desire "to trigger a change or social transformation" (Rey-Martí, Ribeiro-Soriano, \& Palacios-Marqués, 2016, p. 1651). Social entrepreneurship focuses on social value and collective needs rather than on personal interests and expectations (Noruzi, Westover, \& Rahimi, 2010), developing its activities on path-break changes or innovation (Munshi, 2010), by retrieving, mobilizing, and combining resources to create products and/or services (Defourny \& Nyssens, 2010) to solve social problems and satisfy social needs (Yunus, 2007). To fulfil this mission, social entrepreneurs conceive innovative use and combination of resources (Carraher, Welsh, \& Svilokos, 2016) that represent an important source for technology enhancement (Mulloth, Kickul, \& Gundry, 2016). Often, social entrepreneurship is an attractive outlet for technology companies and for compassionate researchers that share the goal of this kind of entrepreneurship and aim to collaborate integrating the scientific and the manufacturing capacity (Seelos \& Mair, 2005). This is due to social entrepreneurship's needs to create and develop new products, service or market segments, leveraging on innovation and technologies, achieving business goals and addressing social challenges (Wood, 2010). Developing and adopting technologies that yield a competitive advantage and enhance the quality of life becomes a must for social entrepreneurs (Wood, 2010).

Notwithstanding the undoubted practical relevance that technology has in social entrepreneurship and although there is a general scholarly agreement about the relevance of innovation and technology to enhance and improve business performance, these concepts in the field of social entrepreneurship remain still theoretically under-researched (Mulgan, Tucker, Ali, \& Sanders, 2007; Phillips, Lee, Ghobadian, O'Regan, \& James, 2015). Given the statements above, inspired by the curiosity to underscore whether a new stream of research is being born (Alvesson \& Sandberg, 2011), and following the call of Abu-Saifan (2012) to propose theoretical studies in the social entrepreneurship field, this work conducts a bibliometric analysis of academic articles that reference 
technology in examinations of social entrepreneurship to orient scholars to know which journals and authors to consult when studying the topic. To accomplish this analysis, the first section of this paper chapter is devoted to the presentation of the literature background underlying this topic, specifically social entrepreneurship, and technology in social entrepreneurship. The second and the third sections describe the method, data and results of the analysis. Finally, the implications and limitations of the bibliometric investigation that is performed in this study are discussed.

\section{Theoretical Background}

\subsection{Social Entrepreneurship: Concept, Mission and Goals}

Social entrepreneurship is a relatively new topic, obtaining researchers' attention because of social relevance and the boom of this kind of business. Despite the numerous definitions that turn around the concept of entrepreneurship, what concerns social entrepreneurship is still in progress and determines the proliferation of concepts, definitions and contents sometimes even contrasting with each other (Rey-Martí et al., 2016). Austin, Stevenson and Wei-Skillern (2006) consider social entrepreneurship a section of the entrepreneurship body of literature, with several specificities and commonalities concerning other kinds of entrepreneurship. In line with this perspective, other scholars (Dey, Steyaert, \& Hjorth, 2007) are not convinced about the legitimacy of social entrepreneurship as an autonomous domain of inquiry because of the rhetoric that turns around the phenomenon and that concur in considering that as unequivocally positive. Nevertheless, the increasing trend of academic studies suggests that social entrepreneurship is representing a new line of research. Literature, in this sense, has primarily analysed the phenomenon on the individual level, focusing on social entrepreneurs and their intentions (Peredo \& McLean, 2006), their values and goals (Stevens, Moray, \& Bruneel, 2015), their mission (Dacin, Dacin, \& Tracey, 2011), and their social impact (Rawhouser et al., 2019) at the organizational level, scholars define social entrepreneurship as the means that entrepreneurs have to create a society founded on justice and social wellbeing (Zadek \& Thake, 1997), to reduce poverty and promote social inclusion (Peredo \& McLean, 2006), to combine resources with innovativeness to incentive social change (Carraher et al., 2016), and to promote a source of sustainable competitive advantage for creating social value (Mort, Weerawardena, Sargeant, $\&$ Bennett, 2015). Moreover, some authors focused on the mission of social entrepreneurship undervaluing the importance of economic outcomes (Peredo \& McLean, 2006), while others underline that economic outcomes are part of the mission of social entrepreneurship (Zahra \& Wright, 2016), even if hierarchically is not the primary intention (Dacin et al., 2011; Stevens, Moray, Bruneel, \& Clarysse, 2015). This study disentangles these intricacies, building on the definition proposed by Alford, Brown and Letts (2004) that consider social entrepreneurship as the process that creates new solutions for social problems, activating abilities, resources and networks to promote a sustainable social change. This allows considering social entrepreneurship as a multilevel and multistage phenomenon (Saebi, Foss, \& Linder, 2019) that affects individuals and society by embodying social and business outcomes, crucial for the long-term survival of social enterprises. This concept appears to represent an important point of departure from classical entrepreneurship and the prevalent non-profit and for-profit enterprises.

\subsection{Technology: Concept and Relevance}

Technology is a critical component of firms' success, particularly in the current era, which is characterised by a hypercompetitive and turbulent business environment (Dessì, Floris, \& Sanna, 2014). Since the 1980s, technology has received increasing attention from academics and practitioners, and scholars have pointed out several definitions, concepts, procedures and considerations (Liao, 2005). Pennings (1975) argue that technology is the means that organizations use to convert inputs into output. This umbrella definition includes several aspects and kinds of technology that, as argued by Brey (2010), are very difficult to define and circumscribe. Volti $(2009$, p. 6$)$ defines technology as "a system created by humans that uses knowledge and organization to produce objects and techniques for attaining specific goals". Technology, in this view, shows the ability to perform specific function, purpose and contribute to attaining a well-defined goal (Carroll, 2017), and comprehends information technology (Turban, 2008), digital technology (Giones \& Brem, 2017), green technology (Chen, Luo, Sato, Wakatsuki, \& Masunaga, 2009; Chen, 2013), and other kinds of technology that are linked to business needs (Phaal, Farrukh, \& Probert, 2001). In fact, the core characteristic of technology is its applicability to problem-solving. In this paper, innovation is considered as a specific type of knowledge that may also be embodied within a physical artefact, such as a machine, component, system or product (Phaal et al., 2001). It explains its relevance in its practical feasibility to resolve business needs and traits new business perspectives. 


\subsection{Technology in Social Entrepreneurship}

Social entrepreneurship refers to the ability to creating innovative solutions for social concerns, mobilizing resources to pursue social and economic goals. This means that social entrepreneur is an important source of creativity and innovation (Bacq, Ofstein, Kickul, \& Gundry, 2015), and social entrepreneurship encompasses an ample range of innovative praxes in social and business domains (Nicholls, 2008), by stimulating the conception and the adoption of new technologies (Mulloth et al., 2016). In addition, social entrepreneurship often represents a push for other firms to develop new technologies and promote social innovations (Surie, 2017). This means that this kind of entrepreneurship promotes technological advancement in order to endorse economic growth, progress and social well-being, and to be competitive in the market (Wilson \& Post, 2013), especially in the current globalized world (Zahra, Rawhouser, Bhawe, Neubaum, \& Hayton, 2008). Moreover, because of the mission of social entrepreneurship, an increasing attention is oriented to green technologies that involve in energy-saving, waste recycling, green product design, pollution prevention and reduction and on environmental protection (Y. S. Chen, 2013), in line with the suggestions of Bruntland report (1987). In fact, social entrepreneurship acts as a change agent, transforming socially responsible principles into business and commercial ideas (Schwab, 2008) through technologies and innovations to identify both new business opportunities to profit and addressing social challenges (Hadad \& Cantaragiu, 2017).

Given the statements above, notwithstanding scholars are generally agreed about the relevance of technology to enhance and improve business performance, this concept in the field of social entrepreneurship remains relatively under researched (Mulgan et al., 2007; Phillips et al., 2015), and it deserves more attention to contribute to a social entrepreneurship theory building. For this reason and to follow the call of Abu-Saifan (2012) which argues that as social entrepreneurship has flourished at the practical level, it lacks theoretical level, this research tries to link social entrepreneurship as a new discipline and research field to technology and innovation theories. To do this, this paper carries out a bibliometric analysis to analyze academic studies that jointly consider technology and social entrepreneurship to understand whether a new stream of research is being born and of addressing interested scholars towards specific authors, journals and articles.

\section{Methodology}

Bibliometric exploration consists of applying a statistical method to assess both qualitative and quantitative considerations through the investigation of publications in a specific field, detecting tendencies within a discipline (De Bakker, Groenewegen, \& Den Hond, 2005). Moreover, this analysis, already used in social entrepreneurship studies (Rey-Martí et al., 2016), provides interesting information for scholars to investigate academic publications (Duque Oliva, Cervera Taulet, \& Rodríguez Romero, 2006), to evaluate the influence of journals (Baumgartner \& Pieters, 2003), to consider the scientific impact (Van Dalen \& Henkens, 2001), to obtain the intellectual structure of a field (Marku, Castriotta, \& Di Guardo, 2017), and to observe a specific field evolution (Hung, 2012). In addition, as underlined by De Bakker et al. (2005), this analysis represents an innovation with reference to traditional literature reviews and appears particularly suitable for studying technology in social entrepreneurship studies. To do this, this work retrieved academic articles from Web of Science (WoS) database, as one of the largest databases that include scientific documents from different disciplines. This span of time was 1990-2019 and was chosen because, during these twenty years, an increased number of studies have examined this specific topic. This increased interest is particularly pronounced from 1996 to 2019. To achieve a broader perspective, we extended our retrieval of citations to the ten years before 1990, utilising the keyword combinations detailed below. First, we selected all of the articles that were included and indexed in the WoS database that contained the following keywords: "Social Entrepreneurship" OR "Social Entrepreneur" OR Social Enterprise". We obtained 3,064 academic articles from this search. Second, we selected all of the academic articles that contained the word "Technology". Table 1 highlights the top 50 key words resulting from search outcomes.

This search retrieved more than 1,221,286 articles. We then combined the two searches and identified 180 documents that we considered without further refinements. The bibliometric tool search was performed in autumn 2019. From the retrieved list of documents, the different investigative analysis was generated. Various rankings that relate to the publication quantities, citations, countries, institutions, authors and core journals of the articles in the database are presented in the following sections. 
Table 1. The top 50 keywords resulting from search outcomes

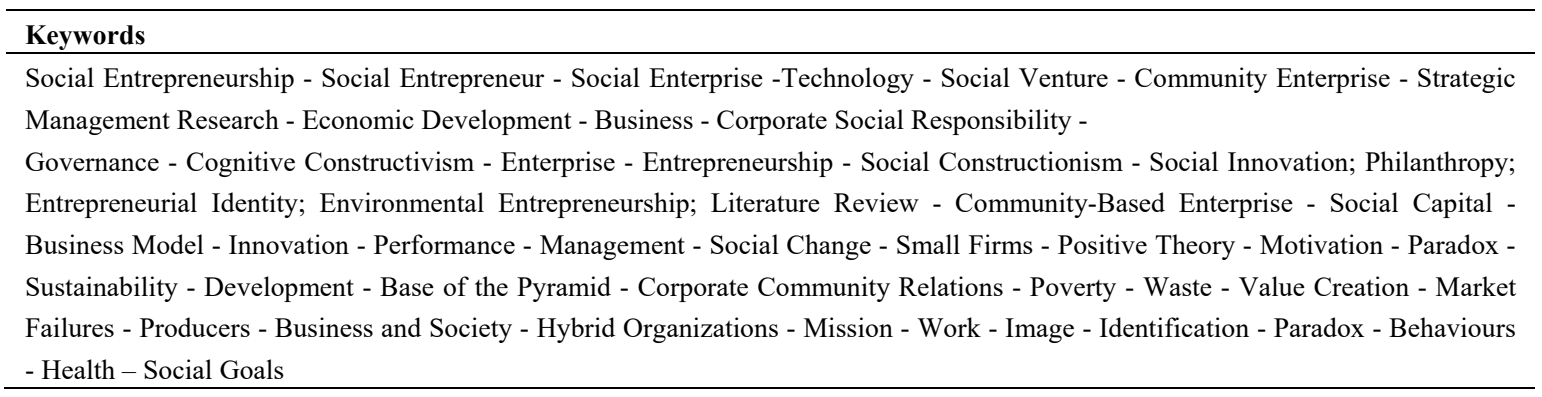

\section{Results and Discussion}

A total of 180 articles were selected for the analysis. Table 2 shows the number of papers that were published between 1990 and 2019 that simultaneously contained at least one of the aforementioned keywords. Since no academic articles were found between 1990 and 1996, in the following tables and figures it is omitted to indicate that time period.

Table 2. The publication years for articles in the WoS database between 1990 and 2019 that examine technology in social entrepreneurship

\begin{tabular}{lll}
\hline Publication Years & Article Count & $\%$ \\
\hline 2019 & 22 & 12.2 \\
2018 & 23 & 12.8 \\
2017 & 24 & 13.3 \\
2016 & 29 & 16.1 \\
2015 & 19 & 10.5 \\
2014 & 14 & 7.8 \\
2013 & 13 & 7.2 \\
2012 & 12 & 6.7 \\
2011 & 5 & 2.7 \\
2010 & 10 & 5.5 \\
2009 & 1 & 0.6 \\
2008 & 1 & 0.6 \\
2007 & 2 & 1.1 \\
2006 & 2 & 1.1 \\
2003 & 1 & 0.6 \\
2002 & 1 & 0.6 \\
1996 & 1 & 0.6 \\
$1990 / 1995$ & 0 & 0 \\
\hline
\end{tabular}

Figure 1 reveals that between 1996 and 2019, an upward trend has been observed with respect to the number of publications that address technology in social entrepreneurship. In particular, this number has risen considerably during the last eight years of the examined time period. Table 1 indicates that since 2015, there has been considerable interest in this topic from scholars, and the number of publications regarding this topic has increased steadily from 2012 to the present day. Notably, this number of publications has almost doubled between 2012 and 2019. The increasing number of articles about technological aspects within social entrepreneurship studies demonstrates the existence of a strong academic interest on this subject (the 2019 data are partial, but the trend appears to demonstrate that this growth is assured). 


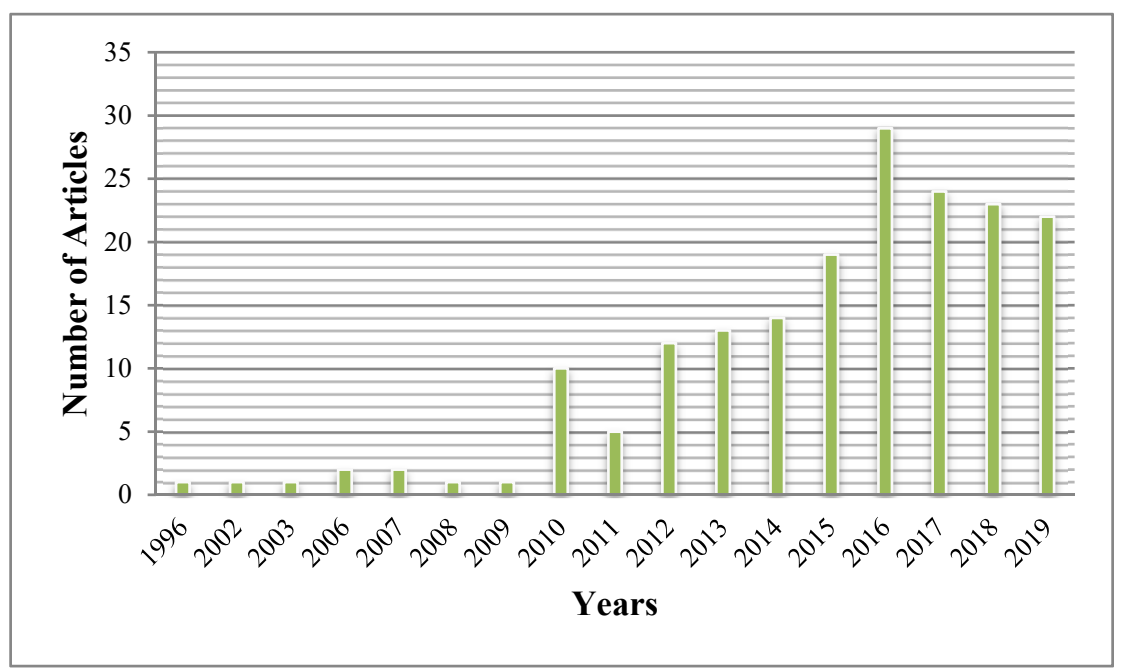

Figure 1. The number of articles in the WoS database between 1990 and 2019 that address technology in family businesses, organised by publication year

Perhaps, a more interesting finding than the number of publications regarding technology in social entrepreneurship is the number of citations by year of these publications, which is depicted in figure 2 . These citation trends reveal the rapid development of this topic, particularly since 2014; a marked increase in citations has particularly occurred during the previous two years (2017 and 2018). The enlarged number of citations regarding this topic reveals that scholarly interest is constantly growing, and this suggests that the argument is generating a niche of interest and may engender a new field in the study of social entrepreneurship.

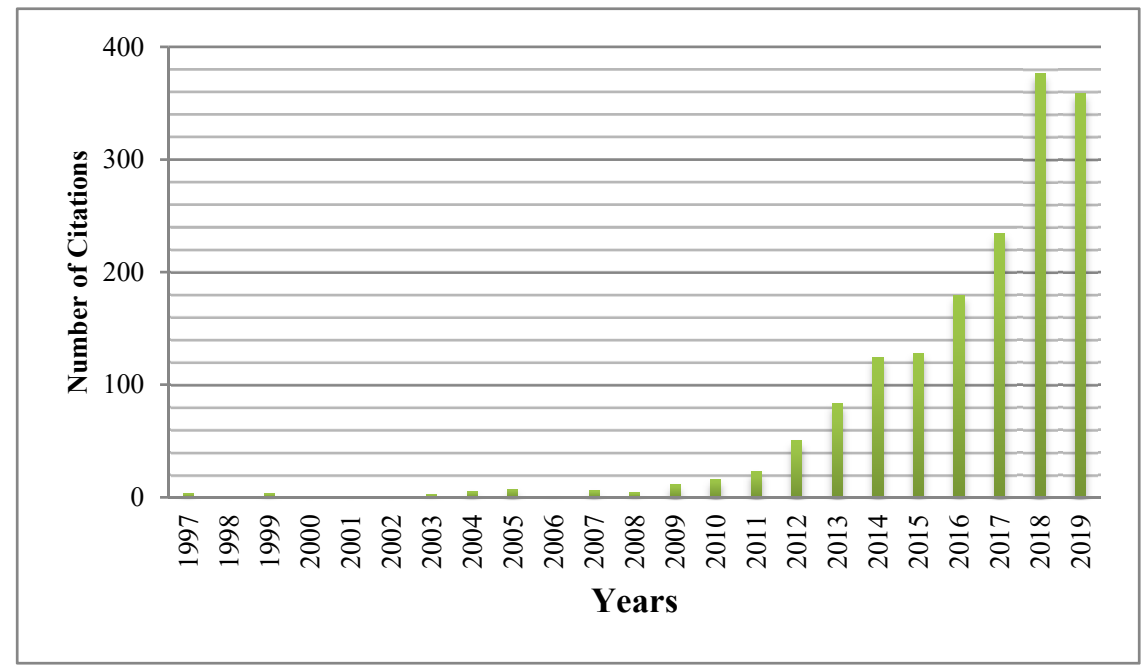

Figure 2. The number of citations between 1997 and 2019 for publications in the WoS database that address technology in social entrepreneurship

Figure 3 compares and summarizes these two trends, which allows us to observe a common trajectory. Unsurprisingly, the trend is more evident for the number of citations than for the number of publications; these trends reveal that the interest of scholars with respect to the topic of technology in social entrepreneurship is increasing in its importance and relevance. 


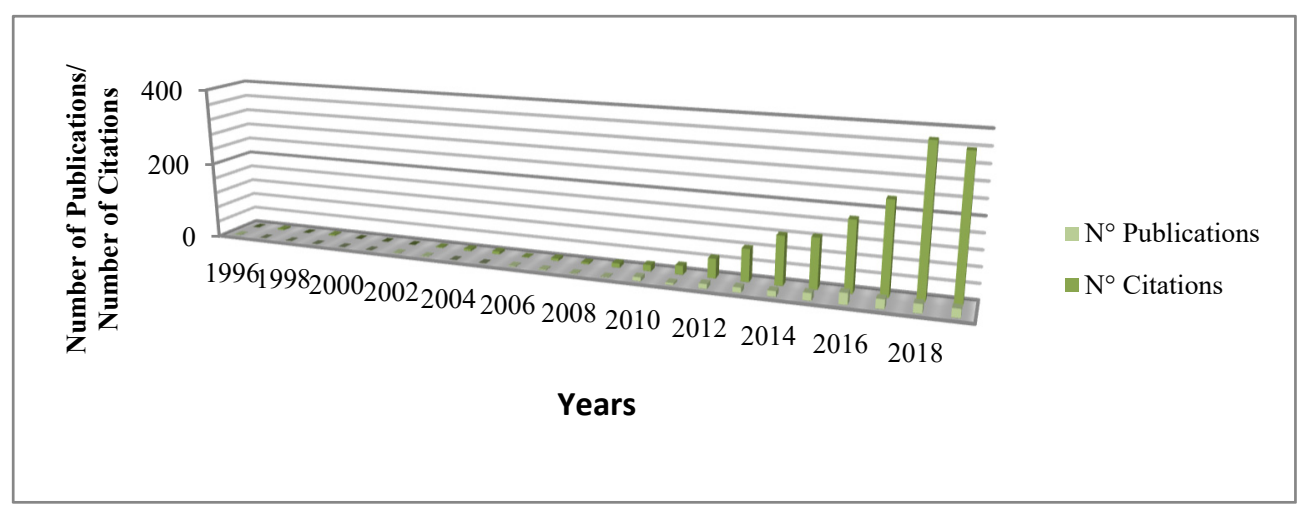

Figure 3. A year-by-year comparison of the trends for the number of publications regarding technology in social entrepreneurship and the number of citations of these publications between 1990 and 2019

Table 3 and Figure 4 depict the number of papers published on this topic in each country. The geographic distribution of scientific production is dominated by the United States of America, which contributed almost 32\% of all of the relevant papers that were published during the twenty-three years that are examined in this study. Scholars are also produced high-impact original research in England, Australia, China, Canada, Netherlands, Scotland and Spain. Focusing on European countries, 69 articles were published, around 38\% of the whole of articles assessed in this work.

The dominant position of the United States should be interpreted with caution because this may be at least partially related to the bias of the social science publications towards Anglo-Saxon countries. In fact, the U.S. produces nearly $60 \%$ of the research output across all of the social science outlets, either singularly or through scientific cooperation (Van Leeuwen, 2006). Moreover, the marked differences among countries with respect to the number of published papers about technology in social entrepreneurship could also be explained in part by differences in population, business models, enterprise size and economic scenario.

Table 3. Rankings of the number of publications between 1990 and 2019 that address technology in social entrepreneurship organised by country/territory.

\begin{tabular}{lll}
\hline Country or Territory & Article Count & \% \\
\hline Usa & 36 & 20.0 \\
England & 27 & 15.0 \\
Australia & 12 & 6.7 \\
People's R. of China & 12 & 6.7 \\
Canada & 8 & 4.5 \\
Netherlands & 7 & 3.9 \\
Scotland & 7 & 3.9 \\
Spain & 7 & 3.9 \\
Germany & 6 & 3.3 \\
India & 6 & 3.3 \\
France & 5 & 2.7 \\
Malaysia & 5 & 2.7 \\
Taiwan & 5 & 2.7 \\
Finland & 4 & 2.2 \\
Indonesia & 4 & 2.2 \\
South Africa & 4 & 2.2 \\
Italy & 3 & 1.7 \\
Portugal & 3 & 1.7 \\
Singapore & 3 & 1.7 \\
South Korea & 3 & 1.7 \\
Sweden & 3 & 1.7 \\
Thailand & 3 & 1.7 \\
U. A. Emirates & 3 & 1.7 \\
Austria & 2 & 1.1 \\
Ireland & 2 & 1.1 \\
\hline & &
\end{tabular}




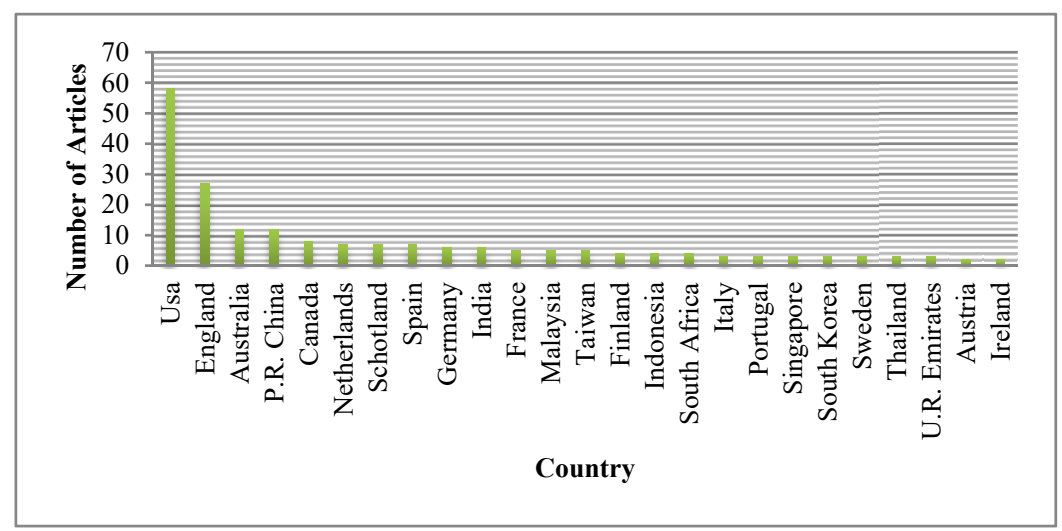

Figure 4. The number of articles that were produced between 1990 and 2019 that addressed technology in the social entrepreneurship, depicted by country/territory

To determine the number of core journals that published articles addressing the specific topic of interest, we can use Bradford's Law as a general guideline (Bradford, 1934). This principle states that journals within a single field can be divided into three categories, each of which contains the same number of articles: (a) a core of journals on the subject that are relatively few in number but account for approximately one third of all the articles; (b) a second group of journals that accounts for the same number of relevant articles as the first category but includes a larger number of journals; and (c) a third group of journals that accounts for the same number of articles as the second group but includes an even larger number of journals. Although Bradford's Law is not statistically accurate, it is commonly used as a general rule of thumb.

In this case, as underlined in Table 4 and Figure 5, considering only journals, in total 112 (excluding proceedings paper, review, early access, correction, editorial material) three journals contained 12 relevant articles, and 8 journals contained another 16 relevant articles. In particular, Technological Forecasting and Social Change, Journal of Social Entrepreneurship and Entrepreneurship Theory and Practice published one third of the examined papers. Thirty-three journals published the next third of the papers of interest, whereas sixty-eight journals published the last third of the papers in question.

Table 4. The journals that published only articles between 1990 and 2019 that addressed technology in social entrepreneurship and the number of articles that were published by each of these journals

\begin{tabular}{lll}
\hline Journal Publication & Article Count & $\mathbf{\%}$ \\
\hline Technological Forecasting and Social Change & 5 & 4.5 \\
Journal of Social Entrepreneurship & 4 & 3.6 \\
Entrepreneurship Theory and Practice & 3 & 2.7 \\
Information Communication Society & 2 & 1.7 \\
Information System Journal & 2 & 1.7 \\
International Journal of Entrepreneurship and Innovation & 2 & 1.7 \\
Science Technology and Society & 2 & 1.7 \\
Sustainability & 2 & 1.7 \\
Technovation & 2 & 1.7 \\
World Development & 2 & 1.7 \\
World Journal of Entrepreneurship Management and Sustainable Development & 2 & 1.7 \\
Academy of Management Journal & 1 & 0.9 \\
Addiction Research Theory & 1 & 0.9 \\
African Journal of Business Management & 1 & 0.9 \\
Archives of Disease in Childhood & 1 & 0.9 \\
Asia Pacific Journal of Management & 1 & 0.9 \\
Asian Journal of Law and Society & 1 & 0.9 \\
Asian Women & 1 & 0.9 \\
Atlantic Law Journal & 1 & 0.9 \\
BMC Pregnancy and Childbirth & 1 & 0.9 \\
\hline
\end{tabular}




\begin{tabular}{|c|c|c|}
\hline Business Peace and Sustainable Development & 1 & 0.9 \\
\hline Cahiers Agricultures & 1 & 0.9 \\
\hline Cogent Business Management & 1 & 0.9 \\
\hline Critical Sociology & 1 & 0.9 \\
\hline International Journal of Knowledge Based Development & 1 & 0.9 \\
\hline Iranian Studies & 1 & 0.9 \\
\hline International Journal of Technology Management & 1 & 0.9 \\
\hline Journal of Business Ethics & 1 & 0.9 \\
\hline Journal of Developing Societies & 1 & 0.9 \\
\hline Journal of Entrepreneurship and Public Policy & 1 & 0.9 \\
\hline Journal of International Management & 1 & 0.9 \\
\hline Journal of Management Organization & 1 & 0.9 \\
\hline Journal of Material Culture & 1 & 0.9 \\
\hline Journal of Sport Management & 1 & 0.9 \\
\hline Journal of the Association for Information System & 1 & 0.9 \\
\hline Journal of the American College Radiology & 1 & 0.9 \\
\hline New Zeeland of Educational Studies & 1 & 0.9 \\
\hline Nordicom Review & 1 & 0.9 \\
\hline R\&D Management & 1 & 0.9 \\
\hline Research Policy & 1 & 0.9 \\
\hline Resources Conservation and Recycling & 1 & 0.9 \\
\hline Revista de Cercetare si Interventie Sociala & 1 & 0.9 \\
\hline South Asian Journal of Business Studies & 1 & 0.9 \\
\hline Strategic Entrepreneurship Journal & 1 & 0.9 \\
\hline Studies in History and Philosophy of Science & 1 & 0.9 \\
\hline Sustainability Science & 1 & 0.9 \\
\hline Universal Access in the Information Society & 1 & 0.9 \\
\hline University of Illinois Law Review & 1 & 0.9 \\
\hline Current Science & 1 & 0.9 \\
\hline Design and Culture & 1 & 0.9 \\
\hline Education and Training & 1 & 0.9 \\
\hline Educational Technology Society & 1 & 0.9 \\
\hline Ekonomsky Vjesnik & 1 & 0.9 \\
\hline Energy Environment & 1 & 0.9 \\
\hline European Journal for Sport and Society & 1 & 0.9 \\
\hline European Journal of International Management & 1 & 0.9 \\
\hline European Journal of Marketing & 1 & 0.9 \\
\hline European Journal of Sustainable Development & 1 & 0.9 \\
\hline Experimental Agriculture & 1 & 0.9 \\
\hline Forum for Development Studies & 1 & 0.9 \\
\hline Global Business Review & 1 & 0.9 \\
\hline Global Nest Journal & 1 & 0.9 \\
\hline Health Affairs & 1 & 0.9 \\
\hline Health Sociology Review & 1 & 0.9 \\
\hline Hts Teologies Studies & 1 & 0.9 \\
\hline Information Economics and Policy & 1 & 0.9 \\
\hline Information System Frontiers & 1 & 0.9 \\
\hline Innovation Organization Management & 1 & 0.9 \\
\hline International Journal of Entrepreneurial Behaviour Research & 1 & 0.9 \\
\hline International Journal of Entrepreneurial Venturing & 1 & 0.9 \\
\hline International Journal of Indian Culture and Business Management & 1 & 0.9 \\
\hline International Journal of Interactive Multimedia and Artificial Intelligence & 1 & 0.9 \\
\hline International Journal of Productivity and Performance Management & 1 & 0.9 \\
\hline IT Information Technology & 1 & 0.9 \\
\hline Journal of Asia Business Studies & 1 & 0.9 \\
\hline Journal of Cleaner Production & 1 & 0.9 \\
\hline
\end{tabular}




\begin{tabular}{lll}
\hline Journal of Economic Issues & 1 & 0.9 \\
Journal of International Development & 1 & 0.9 \\
Journal of Knowledge Management & 1 & 0.9 \\
Journal of Management Studies & 1 & 0.9 \\
Journal of Small Business and Enterprise Development & 1 & 0.9 \\
Journal of Strategic Information System & 1 & 0.9 \\
Media Culture Society & 1 & 0.9 \\
Mis Quarterly & 1 & 0.9 \\
Public Policy and Administration & 1 & 0.9 \\
Qualitative Market Research & 1 & 0.9 \\
Science Education & 1 & 0.9 \\
Small Business Economics & 1 & 0.9 \\
Social Enterprise Journal & 1 & 0.9 \\
Social Inclusion & 1 & 0.9 \\
Sustainable Energy Technologies and Assessments & 1 & 0.9 \\
Studies in Comparative International Development & 1 & 0.9 \\
Supply Chain Management in International Journal & 1 & 0.9 \\
Water & 1 & 0.9 \\
Work Employment and Society & 1 & 0.9 \\
\hline
\end{tabular}

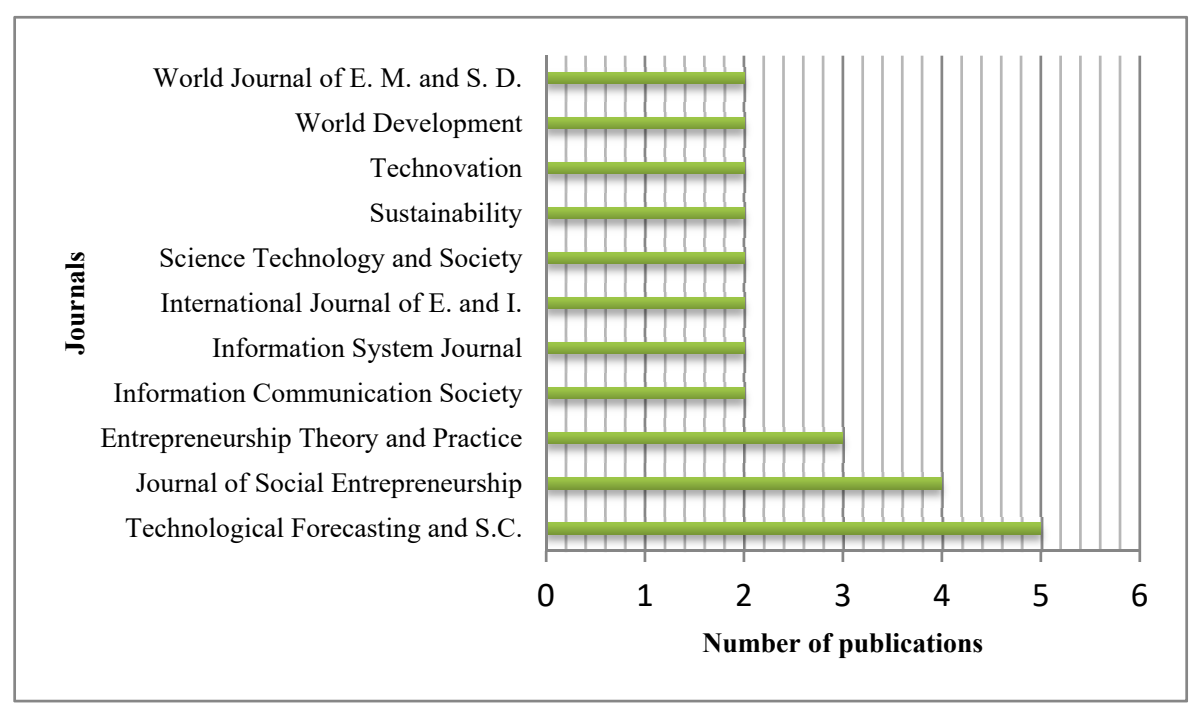

Figure 5. A depiction of the 11 most productive journals between 1990 and 2019 with respect to publishing articles that address technology in social entrepreneurship

Table 5 indicates the authors who published articles in the examined time period regarding the topic of interest. The production of articles about technology in social entrepreneurship is very diversely distributed. There is no single author who dominates this topic through the production of a plethora of articles. The table below shows the 25 most productive authors. 
Table 5. A ranking of the 25 most productive authors between 1990 and 2019 with respect to technology in social entrepreneurship

\begin{tabular}{|c|c|c|}
\hline Scholars & $\mathrm{N}^{\circ}$ of Articles & Country \\
\hline Mehta K. & 7 & Emory University, Atlanta, Usa \\
\hline Mulloth B. & 4 & University of Virginia, Usa \\
\hline Desa G. & 3 & San Francisco State University, Usa \\
\hline Greblikaite J. & 3 & $\begin{array}{l}\text { Inst Business \& Rural Dev Res } \\
\text { Akademija, Lithuania }\end{array}$ \\
\hline Monroe-White T. & 3 & $\begin{array}{l}\text { Berry Coll Campbell Sch Business } \\
\text { MT Berry, GA, Usa }\end{array}$ \\
\hline Purnomo D. & 3 & $\begin{array}{l}\text { Institut Teknologi Sepuluh Nopember } \\
\text { Surabaya, Indonesia } \\
\text { University of Tennessee System }\end{array}$ \\
\hline Roundy P.T. & 3 & $\begin{array}{l}\text { Dept Mkt \& Entrepreneurship } \\
\text { Chattanooga, TN, Usa }\end{array}$ \\
\hline Carsrud A.L. & 2 & Abo Akademi University, Finland \\
\hline Goyal S. & 2 & $\begin{array}{l}\text { Inst Competitiveness } \\
\text { Gurgaon, Haryana, India } \\
\text { University of York - UK }\end{array}$ \\
\hline Howorth C. & 2 & $\begin{array}{l}\text { Sustainable \& Eth Entrepreneurship } \\
\text { York, N Yorkshire, England } \\
\text { NYU Stern Sch Business }\end{array}$ \\
\hline Lee M. & 2 & $\begin{array}{l}\text { Dept Management \& Org } \\
\text { New York, NY, Usa } \\
\text { University of Oklahoma System }\end{array}$ \\
\hline Lumpkin G.T. & 2 & $\begin{array}{l}\text { Price Coll Business } \\
\text { Norman, OK, Usa }\end{array}$ \\
\hline Koch J.L. & 2 & $\begin{array}{l}\text { United States Forest Service } \\
\text { Usda Delaware, OH, Usa } \\
\text { Universitas Negeri Semarang }\end{array}$ \\
\hline Kurniawan K. & 2 & $\begin{array}{l}\text { Fac Educ, Gunungpati, Semarang, } \\
\text { Indonesia } \\
\text { University of San Diego }\end{array}$ \\
\hline Meyskens M. & 2 & $\begin{array}{l}\text { Dept Management Law \& Eth } \\
\text { San Diego, CA, Usa }\end{array}$ \\
\hline Mohamed S. & 2 & $\begin{array}{l}\text { Spans M Sdn Bhd, George Town, } \\
\text { Malaysia } \\
\text { Universiti Teknologi Malaysia }\end{array}$ \\
\hline Sohel M.H. & 2 & $\begin{array}{l}\text { Fac Management } \\
\text { Skudai, Johor, Malaysia } \\
\text { Jilin University }\end{array}$ \\
\hline Yang J. & 2 & $\begin{array}{l}\text { Zhuhai Coll } \\
\text { Zhuhai, Guangdong, Peoples R China } \\
\text { Seattle University }\end{array}$ \\
\hline Zhao Y. & 2 & $\begin{array}{l}\text { Albers Sch Business \& Econ } \\
\text { Seattle, WA, Usa }\end{array}$ \\
\hline Abbas Q. & 1 & CAREC Inst, Urmqhi, Peoples R China \\
\hline Abrishami P. & 1 & $\begin{array}{l}\text { Maastricht University, Maastricht, } \\
\text { Netherlands }\end{array}$ \\
\hline Aggarwal S. & 1 & $\begin{array}{l}\text { University of Illinois System, Chicago, } \\
\text { IL, Usa }\end{array}$ \\
\hline Ahmad A.J. & 1 & $\begin{array}{l}\text { University College London, London, } \\
\text { England }\end{array}$ \\
\hline Al Abd M. & 1 & $\begin{array}{l}\text { American University of Sharjah, Sharjah, } \\
\text { U.A.Emirates }\end{array}$ \\
\hline Alfaro F. & 1 & $\begin{array}{l}\text { University of Vermont Burlington, VT, } \\
\text { Usa }\end{array}$ \\
\hline
\end{tabular}

Table 6 demonstrates that Penn State University and Pennsylvania Commonwealth System of Higher Education PCSHE, which are responsible for 14 of the examined articles, are the most productive institutions in the field of interest, followed by California State University System and State University System of Florida that have produced four of the examined articles. The main institutions with respect to the production of research 
regarding the topic of interest are located in the United States; this finding is consistent with the distribution of relevant articles per country.

Tables 6 . The ranking of the 15 most productive institutions with respect to publications between 1990 and 2019 that address technology in social entrepreneurship

\begin{tabular}{lll}
\hline Institutions & Article Count & \% \\
\hline Penn State University & 7 & 3.889 \\
Pennsylvania Commonwealth System of Higher Education Pcshe & 7 & 3.889 \\
California State University System & 4 & 2.222 \\
State University System of Florida & 4 & 2.222 \\
Georgia Institute of Technology & 3 & 1.667 \\
Massachusetts Institute of Technology Mit & 3 & 1.667 \\
San Francisco State University & 3 & 1.667 \\
Santa Clara University & 3 & 1.667 \\
Sheffield Hallam University & 3 & 1.667 \\
Universitas Padjadjara & 3 & 1.667 \\
University of California System & 3 & 1.667 \\
University of East Anglia & 3 & 1.667 \\
University System of Georgia & 3 & 1.667 \\
Aalto University & 2 & 1.111 \\
Abo Akademy University & 2 & 1.111 \\
\hline
\end{tabular}

The following table shows the 50 most-cited articles on the topic of technology in social entrepreneurship. The 10 most-cited articles are published in very different journals; in particular, World Development has published about $30 \%$ of these articles and Strategic Entrepreneurship Journal has published about $20 \%$ of them. The remaining articles, including the most-cited article regarding the topic in question, are published in five different journals.

Table 7. A ranking of the 50 most-cited articles that were published between 1990 and 2019 and address technology in social entrepreneurship

\begin{tabular}{|c|c|c|c|c|c|}
\hline & Title & Authors & Journal & Publication Year & Tot. Citations \\
\hline 1 & $\begin{array}{l}\text { Capitals and capabilities: A framework for } \\
\text { analyzing peasant } \\
\text { livelihoods and poverty }\end{array}$ & Bebbington, A & World Development & 1999 & 814 \\
\hline 2 & $\begin{array}{l}\text { Research in social entrepreneurship: past } \\
\text { contributions and future opportunities }\end{array}$ & $\begin{array}{l}\text { Short, Jeremy C.; Moss, } \\
\text { Todd W.; Lumpkin, G. T. }\end{array}$ & $\begin{array}{l}\text { Strategic } \\
\text { Entrepreneurship } \\
\text { Journal }\end{array}$ & 2009 & 422 \\
\hline 3 & Entrepreneurial risk taking in family firms & Zahra, SA & $\begin{array}{l}\text { Academy of } \\
\text { Management Annals }\end{array}$ & 2014 & 333 \\
\hline 4 & $\begin{array}{l}\text { The Legitimacy of Social Entrepreneurship: } \\
\text { Reflexive Isomorphism in a } \\
\text { Pre-Paradigmatic Field }\end{array}$ & Nicholls, Alex & $\begin{array}{l}\text { Entrepreneurship } \\
\text { theory and Practice }\end{array}$ & 2010 & 307 \\
\hline 5 & $\begin{array}{l}\text { A Positive Theory of Social } \\
\text { Entrepreneurship }\end{array}$ & Santos, Filipe M. & $\begin{array}{l}\text { Journal of Business } \\
\text { Ethics }\end{array}$ & 2012 & 300 \\
\hline 6 & $\begin{array}{l}\text { Social Enterprises as Hybrid Organizations: } \\
\text { A Review and Research Agenda }\end{array}$ & $\begin{array}{l}\text { Doherty, Bob; Haugh, } \\
\text { Helen; Lyon, Fergus }\end{array}$ & $\begin{array}{l}\text { International Journal of } \\
\text { Management Reviews }\end{array}$ & 2014 & 269 \\
\hline 7 & $\begin{array}{l}\text { Innovation for Inclusive Growth: Towards a } \\
\text { Theoretical Framework and a Research } \\
\text { Agenda }\end{array}$ & $\begin{array}{l}\text { George, Gerard; McGahan, } \\
\text { Anita M.; Prabhu, Jaideep }\end{array}$ & $\begin{array}{l}\text { Journal of Management } \\
\text { Studies }\end{array}$ & 2012 & 189 \\
\hline 8 & $\begin{array}{l}\text { Collective action for smallholder market } \\
\text { access }\end{array}$ & $\begin{array}{lr}\text { Markelova, } & \text { Helen; } \\
\text { Meinzen-Dick, } & \text { Ruth; } \\
\text { Hellin, Jon; et al. } & \end{array}$ & Food Policy & 2009 & 182 \\
\hline 9 & $\begin{array}{l}\text { Social innovation: Moving the field } \\
\text { forward. A conceptual framework }\end{array}$ & Cajaiba-Santana, Giovany & $\begin{array}{l}\text { Technological } \\
\text { Forecasting and Social } \\
\text { Change }\end{array}$ & 2014 & 139 \\
\hline 10 & $\begin{array}{l}\text { Service innovation in the digital age: key } \\
\text { contributions and future directions }\end{array}$ & $\begin{array}{l}\text { Barrett, Michael; Davidson, } \\
\text { Elizabeth; Prabhu, Jaideep; }\end{array}$ & Mis Quarterly & 2015 & 138 \\
\hline
\end{tabular}




\begin{tabular}{|c|c|c|c|c|c|}
\hline & & et al. & & & \\
\hline 11 & $\begin{array}{l}\text { A literature review and perspectives in } \\
\text { reverse logistics }\end{array}$ & $\begin{array}{l}\text { Agrawal, Saurabh; Singh, } \\
\text { Rajesh K.; Murtaza, Qasim }\end{array}$ & $\begin{array}{l}\text { Resources } \\
\text { Conservation } \\
\text { Recycling }\end{array}$ & 2015 & 135 \\
\hline 12 & $\begin{array}{l}\text { Soybeans, development and conservation } \\
\text { on the Amazon frontier }\end{array}$ & Hecht, SB & $\begin{array}{l}\text { Development } \\
\text { Change }\end{array}$ & 2005 & 132 \\
\hline 13 & $\begin{array}{l}\text { Do information and communication } \\
\text { technologies (ICTs) contribute to } \\
\text { development? }\end{array}$ & Heeks, Richard & $\begin{array}{l}\text { Journal of International } \\
\text { Development }\end{array}$ & 2010 & 131 \\
\hline 14 & $\begin{array}{l}\text { Entrepreneurship, Social Capital, and } \\
\text { Institutions: Social and Commercial } \\
\text { Entrepreneurship Across Nations }\end{array}$ & $\begin{array}{l}\text { Estrin, Saul; Mickiewicz, } \\
\text { Tomasz; Stephan, Ute }\end{array}$ & $\begin{array}{l}\text { Entrepreneurship } \\
\text { Theory and Practice }\end{array}$ & 2013 & 128 \\
\hline 15 & $\begin{array}{l}\text { Impact at the 'Bottom of the Pyramid': The } \\
\text { Role of Social Capital in Capability } \\
\text { Development } \quad \text { and } \\
\text { Empowerment }\end{array}$ & $\begin{array}{l}\text { Ansari, Shahzad; Munir, } \\
\text { Kamal; Gregg, Tricia }\end{array}$ & $\begin{array}{l}\text { Journal of Management } \\
\text { Studies }\end{array}$ & 2012 & 126 \\
\hline 16 & $\begin{array}{l}\text { Organizing for Society: A Typology of } \\
\text { Social Entrepreneuring Models }\end{array}$ & $\begin{array}{l}\text { Mair, Johanna; Battilana, } \\
\text { Julie; Cardenas, Julian }\end{array}$ & $\begin{array}{l}\text { Journal of Business } \\
\text { Ethics }\end{array}$ & 2012 & 117 \\
\hline 17 & $\begin{array}{l}\text { Institutions and social entrepreneurship: } \\
\text { The role of institutional voids, institutional } \\
\text { support, and institutional configurations }\end{array}$ & $\begin{array}{l}\text { Stephan, Ute; } \quad \text { Uhlaner, } \\
\text { Lorraine M.; } \\
\text { Christopher }\end{array}$ & $\begin{array}{l}\text { Journal of International } \\
\text { Business Studies }\end{array}$ & 2015 & 112 \\
\hline 18 & $\begin{array}{l}\text { Innovation for Inclusive Business: } \\
\text { Intrapreneurial Bricolage in Multinational } \\
\text { Corporations }\end{array}$ & $\begin{array}{l}\text { Halme, Minna; Lindeman, } \\
\text { Sara; Linna, Paula }\end{array}$ & $\begin{array}{l}\text { Journal of Management } \\
\text { Studies }\end{array}$ & 2012 & 98 \\
\hline 19 & $\begin{array}{l}\text { Sustainable supply chain management in } \\
\text { emerging economies: Environmental } \\
\text { turbulence, institutional voids and } \\
\text { sustainability trajectories }\end{array}$ & Silvestre, Bruno S. & $\begin{array}{l}\text { International Journal of } \\
\text { Production Economics }\end{array}$ & 2015 & 94 \\
\hline 20 & $\begin{array}{l}\text { Social innovation research: An emerging } \\
\text { area of innovation studies? }\end{array}$ & $\begin{array}{l}\text { van der Have, Robert P.; } \\
\text { Rubalcaba, Luis }\end{array}$ & Research Policy & 2016 & 90 \\
\hline 21 & $\begin{array}{l}\text { E-health in low- and middle-income } \\
\text { countries: findings from the Center for } \\
\text { Health Market Innovations }\end{array}$ & $\begin{array}{l}\text { Lewis, Trevor; Synowiec, } \\
\text { Christina; Lagomarsino, } \\
\text { Gina; et al. }\end{array}$ & $\begin{array}{l}\text { Bulletin of the World } \\
\text { Health Organization }\end{array}$ & 2012 & 87 \\
\hline 22 & $\begin{array}{l}\text { Social Innovation and Social } \\
\text { Entrepreneurship: A Systematic Review }\end{array}$ & $\begin{array}{l}\text { Phillips, Wendy; Lee, } \\
\text { Hazel; Ghobadian, Abby; et } \\
\text { al. }\end{array}$ & $\begin{array}{l}\text { Group \& Organization } \\
\text { Management }\end{array}$ & 2015 & 85 \\
\hline 23 & $\begin{array}{l}\text { When and how far is group formation a } \\
\text { route out of chronic poverty? }\end{array}$ & $\begin{array}{l}\text { Thorp, R; Stewart, F; } \\
\text { Heyer, A }\end{array}$ & World Development & 2005 & 83 \\
\hline 24 & $\begin{array}{l}\text { Collective Social Entrepreneurship: } \\
\text { Collaboratively Shaping Social Good }\end{array}$ & $\begin{array}{l}\text { Montgomery, A. Wren; } \\
\text { Dacin, Peter A.; Dacin, M. } \\
\text { Tina }\end{array}$ & $\begin{array}{l}\text { Journal of Business } \\
\text { Ethics }\end{array}$ & 2012 & 81 \\
\hline 25 & $\begin{array}{l}\text { Optimization or Bricolage? Overcoming } \\
\text { Resource Constraints in Global Social } \\
\text { Entrepreneurship }\end{array}$ & $\begin{array}{l}\text { Desa, Geoffrey; Basu, } \\
\text { Sandip }\end{array}$ & $\begin{array}{l}\text { Strategic } \\
\text { Entrepreneurship } \\
\text { Journal }\end{array}$ & 2013 & 72 \\
\hline 26 & $\begin{array}{l}\text { Crescive entrepreneurship in complex } \\
\text { social problems: Institutional conditions for } \\
\text { entrepreneurial engagement }\end{array}$ & $\begin{array}{l}\text { Dorado, Silvia; Ventresca, } \\
\text { Marc J. }\end{array}$ & $\begin{array}{l}\text { Journal of Business } \\
\text { Venturing }\end{array}$ & 2013 & 66 \\
\hline 27 & $\begin{array}{l}\text { Digital education governance: data } \\
\text { visualization, predictive analytics, and } \\
\text { 'real-time' policy instruments }\end{array}$ & Williamson, Ben & $\begin{array}{l}\text { Journal of Education } \\
\text { Policy }\end{array}$ & 2016 & 64 \\
\hline 28 & $\begin{array}{l}\text { Toward a theory of transformative } \\
\text { entrepreneuring: Poverty reduction and } \\
\text { conflict resolution in Rwanda's } \\
\text { entrepreneurial coffee sector }\end{array}$ & $\begin{array}{l}\text { Tobias, Jutta M.; Mair, } \\
\text { Johanna; Barbosa-Leiker, } \\
\text { Celestina }\end{array}$ & $\begin{array}{l}\text { Journal of Business } \\
\text { Venturing }\end{array}$ & 2013 & 60 \\
\hline 29 & $\begin{array}{l}\text { Social entrepreneurship in Sub-Saharan } \\
\text { Africa }\end{array}$ & $\begin{array}{l}\text { Rivera-Santos, Miguel; } \\
\text { Holt, Diane; Littlewood, } \\
\text { David; et al. }\end{array}$ & $\begin{array}{l}\text { Academy } \\
\text { Management } \\
\text { Perspectives }\end{array}$ & 2015 & 59 \\
\hline 30 & $\begin{array}{l}\text { A hard nut to crack! Implementing supply } \\
\text { chain sustainability in an emerging } \\
\text { economy }\end{array}$ & Silvestre, Bruno S. & $\begin{array}{l}\text { Journal of Cleaner } \\
\text { Production }\end{array}$ & 2015 & 57 \\
\hline 31 & $\begin{array}{l}\text { Early Challenges of Nascent Social } \\
\text { Entrepreneurs }\end{array}$ & Renko, Maija & $\begin{array}{l}\text { Entrepreneurship } \\
\text { Theory and Practice }\end{array}$ & 2013 & 56 \\
\hline 32 & $\begin{array}{l}\text { Business as a development agent: evidence } \\
\text { of possibility and improbability }\end{array}$ & $\begin{array}{l}\text { Blowfield, Michael; Dolan, } \\
\text { Catherine S. }\end{array}$ & Third World Quarterly & 2014 & 55 \\
\hline 33 & $\begin{array}{l}\text { Breakthrough without subsidies? PV } \\
\text { business model experiments in the } \\
\text { Netherlands }\end{array}$ & $\begin{array}{l}\text { Huijben, J. C. C. M.; } \\
\text { Verbong, G. P. J. }\end{array}$ & Energy Policy & 2013 & 55 \\
\hline
\end{tabular}




\begin{tabular}{|c|c|c|c|c|c|}
\hline 34 & $\begin{array}{l}\text { New states, new NGOs? Crises and } \\
\text { transitions among rural development NGOs } \\
\text { in the Andean region }\end{array}$ & Bebbington, A & World Development & 1997 & 54 \\
\hline 35 & $\begin{array}{l}\text { Legitimation of New Ventures: A Review } \\
\text { and Research Programme }\end{array}$ & Ueberbacher, Florian & $\begin{array}{l}\text { Journal of Management } \\
\text { Studies }\end{array}$ & 2014 & 53 \\
\hline 36 & $\begin{array}{l}\text { Developing a conceptual framework for } \\
\text { comparing social value creation }\end{array}$ & $\begin{array}{l}\text { Kroeger, Arne; Weber, } \\
\text { Christiana }\end{array}$ & $\begin{array}{l}\text { Academy of } \\
\text { Management Review }\end{array}$ & 2014 & 52 \\
\hline 37 & $\begin{array}{l}\text { Taking Complexity in Food Systems } \\
\text { Seriously: An Interdisciplinary Analysis }\end{array}$ & $\begin{array}{l}\text { Foran, Tira; Butler, James } \\
\text { R. A.; Williams, Liana J.; et } \\
\text { al. }\end{array}$ & World Development & 2014 & 52 \\
\hline 38 & $\begin{array}{l}\text { An in-depth literature review of the waste } \\
\text { electrical and electronic equipment context: } \\
\text { Trends and evolution }\end{array}$ & $\begin{array}{l}\text { Perez-Belis, } \\
\text { Ibanez-Fores, Bovea V. }\end{array}$ & $\begin{array}{l}\text { Waste Management \& } \\
\text { Research }\end{array}$ & 2015 & 50 \\
\hline 39 & $\begin{array}{l}\text { NGOs in a global future: marrying local } \\
\text { delivery to worldwide leverage }\end{array}$ & $\begin{array}{l}\text { Edwards, M; Hulme, D; } \\
\text { Wallace, } \mathrm{T}\end{array}$ & $\begin{array}{l}\text { Public Administration } \\
\text { and Development }\end{array}$ & 1999 & 50 \\
\hline 40 & $\begin{array}{l}\text { The Social and Economic Mission of Social } \\
\text { Enterprises: Dimensions, Measurement, } \\
\text { Validation, and Relation }\end{array}$ & $\begin{array}{l}\text { Stevens, Robin; Moray, } \\
\text { Nathalie; Bruneel, Johan }\end{array}$ & $\begin{array}{l}\text { Entrepreneurship } \\
\text { Theory and Practice }\end{array}$ & 2015 & 49 \\
\hline 41 & $\begin{array}{l}\text { Rural entrepreneurship or entrepreneurship } \\
\text { in the rural - between place and space }\end{array}$ & $\begin{array}{l}\text { Korsgaard, Steffen; Muller, } \\
\text { Sabine; Tanvig, Hanne } \\
\text { Wittorff }\end{array}$ & $\begin{array}{l}\text { International Journal of } \\
\text { Entrepreneurial } \\
\text { Behaviour }\end{array}$ & 2015 & 49 \\
\hline 42 & $\begin{array}{l}\text { Local institutions, poverty and household } \\
\text { welfare in Bolivia }\end{array}$ & Grootaert, C; Narayan, D & World Development & 2004 & 49 \\
\hline 43 & $\begin{array}{l}\text { Emergence of green business models: The } \\
\text { case of algae biofuel for aviation }\end{array}$ & $\begin{array}{l}\text { Nair, Sujith; Paulose, } \\
\text { Hanna }\end{array}$ & Energy Policy & 2014 & 48 \\
\hline 44 & $\begin{array}{l}\text { Understanding gender dimensions of } \\
\text { agriculture and climate change in } \\
\text { smallholder farming communities }\end{array}$ & $\begin{array}{l}\text { Jost, Christine; Kyazze, } \\
\text { Florence; Naab, Jesse; et al. }\end{array}$ & $\begin{array}{l}\text { Climate } \\
\text { Development }\end{array}$ & 2016 & 47 \\
\hline 45 & $\begin{array}{l}\text { Electronic waste recovery in Finland: } \\
\text { Consumers' perceptions towards recycling } \\
\text { and re-use of mobile phones }\end{array}$ & $\begin{array}{l}\text { Yla-Mella, Jenni; Keiski, } \\
\text { Riitta L.; Pongracz, Eva }\end{array}$ & Waste Management & 2015 & 47 \\
\hline 46 & $\begin{array}{l}\text { Competing through service innovation: The } \\
\text { role of bricolage and entrepreneurship in } \\
\text { project-oriented firms }\end{array}$ & $\begin{array}{lr}\text { Salunke, } & \text { Sandeep; } \\
\text { Weerawardena, } & \text { Jay; } \\
\text { McColl-Kennedy, Janet R. }\end{array}$ & $\begin{array}{l}\text { Journal of Business } \\
\text { Research }\end{array}$ & 2013 & 47 \\
\hline 47 & $\begin{array}{l}\text { The double-edged sword of legitimacy in } \\
\text { base-of-the-pyramid markets }\end{array}$ & $\begin{array}{l}\text { Kistruck, Geoffrey M.; } \\
\text { Webb, Justin W.; Sutter, } \\
\text { Christopher J.; et al. }\end{array}$ & $\begin{array}{l}\text { Journal of Business } \\
\text { Venturing }\end{array}$ & 2015 & 46 \\
\hline 48 & $\begin{array}{l}\text { Link, search, interact - The co-evolution of } \\
\text { NGOs and interactive technology }\end{array}$ & Bach, J; Stark, D & $\begin{array}{l}\text { Theory Culture \& } \\
\text { Society }\end{array}$ & 2004 & 45 \\
\hline 49 & $\begin{array}{l}\text { NGO performance - What breeds success? } \\
\text { New evidence from South Asia }\end{array}$ & Edwards, M & World Development & 1999 & 45 \\
\hline 50 & $\begin{array}{l}\text { Comparing drivers, barriers, and } \\
\text { opportunities of business models for } \\
\text { renewable energies: A review }\end{array}$ & $\begin{array}{l}\text { Engelken, Maximilian; } \\
\text { Roemer, Benedikt; } \\
\text { Drescher, Marcus; et al. }\end{array}$ & $\begin{array}{l}\text { Renewable } \\
\text { Sustainable } \\
\text { Reviews }\end{array}$ & 2016 & 44 \\
\hline
\end{tabular}

\section{Conclusion}

This article presented a bibliometric analysis of the academic studies on technology in social entrepreneurship research to identify the most prolific and most cited scholars, the trend in the number of publications and citations, the most relevant journals, the most engaged institutions, and other aspects that allowed to frame the state of the art and the expected trend. We used diverse graphic and tabular representations to describe the development of scholarly interest in this topic. We first considered the evolution of studies regarding this topic by analysing the number of relevant papers that were published in the examined time period, providing the number of citations of these articles and comparing the trend for publications with the trend for citations. We then outlined the geographic distribution of relevant scientific production by country, identified core journals that have published articles addressing the specific topic of interest, recognised the most prolific authors who have addressed this subject, and revealed the most productive institutions with respect to this topic. Finally, we listed the most-cited articles regarding technology in social entrepreneurship studies and identified the publications that contained these articles, enabling a partial connection between these articles and earlier portions of the study. Quantitative evidence supported the idea that the investigated topic has obtaining increasing attention of scholars, especially recently. However, in light of the positive trend that this argument has pertaining, there are rooms for further studies oriented to analyse the ability of social enterprises to adopt technologies to be sustainable and competitive in a hyper-turbulent market in which technology represents a key component. 
Findings offers a useful toolbox to those scholars that are interested in the field of technology in social entrepreneurship, providing interesting information on which journal and authors to check.

This study has some drawbacks mainly referred to the use of WoS as the unique database for the analysis. This database covers the most seminal and impactful academic publications, but other contributions could be ignored, even if equally relevant, because published in journals that are not indexed in WoS database. In this sense, further studies are expected to consult other databases in order to cover a major number of journals, also those with a lower impact factor. Moreover, the analysis presented in this chapter does not consider the fact that recent works are likely less cited than older documents and may not have existed for a sufficient length of time to influence the literature regarding the specific topic of interest. The existing evolutionary phase may be sustained by these investigations, and future research efforts, e.g., the use of additional bibliometric techniques, such as bibliographic coupling or co-citation analysis, may complement these studies by providing a description of technological adoption by social entrepreneurship that draws upon another perspective. These methods could be applied to social network analyses to re-define clusters, measurements and graphic representations.

However, we are reasonably confident that the literature of the chosen time period and of the used database that has been examined in this paper represents the major segment of studies that focus on technology in the context of social entrepreneurship.

In summary, the present study and related investigations offer a quantitative analysis of state-of-the-art research as a complement to (but never a substitute for) traditional qualitative methods of reviewing the existing literature. This method may be used as a tool to recognise the authors, documents, journals, and topics that are most widely disseminated among scholars in a specific field and to identify the relational links among these features of the topic of interest.

\section{References}

Abu-Saifan, S. (2012). Social entrepreneurship: definition and boundaries. Technology Innovation Management Review, 2(2). http://doi.org/10.22215/timreview/523

Alford, S., Brown, L. D., \& Letts, C. W. (2004). Social entrepreneurship: leadership that facilitates societal transformation. Working paper. Center for Public Leadership, Kennedy School of Government.

Alvesson, M., \& Sandberg, J. (2011). Generating research questions through problematization. Academy of Management Review, 36(2), 247-271. https://doi.org/10.5465/amr.2009.0188

Ashraf, M. M., Razzaque, M. A., Liaw, S. T., Ray, P. K., \& Hasan, M. R. (2019). Social business as an entrepreneurship model in emerging economy. Management Decision, 57(5), 1145-1161. https://doi.org/10.1108/MD-04-2017-0343

Austin, J., Stevenson, H., \& Wei-Skillern, J. (2006). Social and commercial entrepreneurship: same, different, or both? Entrepreneurship theory and practice, 30(1), 1-22. https://doi.org/10.1111/j.1540-6520.2006.00107.x

Bacq, S., Ofstein, L. F., Kickul, J. R., \& Gundry, L. K. (2015). Bricolage in social entrepreneurship: How creative resource mobilization fosters greater social impact. The International Journal of Entrepreneurship and Innovation, 16(4), 283-289. https://doi.org/10.5367/ijei.2015.0198

Baumgartner, H., \& Pieters, R. (2003). The structural influence of marketing journals: A citation analysis of the discipline and its subareas over time. Journal of marketing, 67(2), 123-139. https://doi.org/10.1509/jmkg.67.2.123.18610

Bradford, S. C. (1934). Sources of information on specific subjects. Engineering, 137, 85-86.

Brey, P. (2010). Philosophy of technology after the empirical turn. Techné: Research in Philosophy and Technology, 14(1), 36-48. https://doi.org/10.5840/techne20101416

Brundtland, G. H. (1987). Report of the World Commission on environment and development: our common future. United Nations.

Carraher, S. M., Welsh, D. H., \& Svilokos, A. (2016). Validation of a measure of social entrepreneurship. European Journal of International Management, 10(4), 386-402. https://doi.org/10.1504/EJIM.2016.077421

Carroll, L. (2017). A comprehensive definition of technology from an ethological perspective. Social Sciences, 6(4), 126. https://doi.org/10.3390/socsci6040126 
Chell, E., Nicolopoulou, K., \& Karatas-Ozkan, M. (2010). Social entrepreneurship and enterprise: international and innovation perspectives. Entrepreneurship \& Regional Development, 22(6), 485-493. https://doi.org/10.1080/08985626.2010.488396

Chen, X., Luo, A. C., Sato, K., Wakatsuki, T., \& Masunaga, T. (2009). An introduction of a multi-soil-layering system: a novel green technology for wastewater treatment in rural areas. Water and Environment Journal, 23(4), 255-262. https://doi.org/10.1111/j.1747-6593.2008.00143.x

Chen, Y. S. (2013). Towards green loyalty: driving from green perceived value, green satisfaction, and green trust. Sustainable Development, 21(5), 294-308. https://doi.org/10.1002/sd.500

Dacin, M. T., Dacin, P. A., \& Tracey, P. (2011). Social entrepreneurship: A critique and future directions. Organization science, 22(5), 1203-1213. https://doi.org/10.1287/orsc.1100.0620

De Bakker, F. G., Groenewegen, P., \& Den Hond, F. (2005). A bibliometric analysis of 30 years of research and theory on corporate social responsibility and corporate social performance. Business \& society, 44(3), 283-317. https://doi.org/10.1177/0007650305278086

Defourny, J., \& Nyssens, M. (2010). Conceptions of social enterprise and social entrepreneurship in Europe and the United States: Convergences and divergences. Journal of Social Entrepreneurship, 1(1), 32-53. https://doi.org/10.1080/19420670903442053

Dessì, C., Floris, M., \& Sanna, A. (2014). Technology in family business studies. a bibliometric analysis (19912012). Handbook of Research on Techno-Entrepreneurship: How Technology and Entrepreneurship are Shaping the Development of Industries and Companies, 39.

Dey, P., Steyaert, C., \& Hjorth, D. (2007). 6. The rhetoric of social entrepreneurship: paralogy and new language games in academic discourse. Cheltenham, UK, Northampton, MA, USA: Elgar.

Duque Oliva, E. J., Cervera Taulet, A., \& Rodríguez Romero, C. (2006). A bibliometric analysis of models measuring the concept of perceived quality inproviding internet service. Innovar, 16(28), 223-243.

Giones, F., \& Brem, A. (2017). Digital technology entrepreneurship: A definition and research agenda. Technology Innovation Management Review, 7(5).

Hadad, S., \& Cantaragiu, R. (2017). Corporate social entrepreneurship versus social intrapreneurship: same idea, $\begin{array}{llll}\text { different } \quad \text { trajectories? } & \text { Management } \quad \text { \& } & \text { Marketing, } & \text { 12(2), }\end{array}$ https://doi.org/10.1515/mmcks-2017-0016

Hung, J. 1. (2012). Trends of e-learning research from 2000 to 2008: Use of text mining and bibliometrics. British Journal of Educational Technology, 43(1), 5-16. https://doi.org/10.1111/j.1467-8535.2010.01144.x

Liao, S.-h. (2005). Technology management methodologies and applications: A literature review from 1995 to 2003. Technovation, 25(4), 381-393.

Marku, E., Castriotta, M., \& Di Guardo, M. C. (2017). Disentangling the intellectual structure of innovation and M\&A literature. Technological Innovation Networks: Collaboration and Partnership, 47.

Mort, G. S., Weerawardena, J., Sargeant, A., \& Bennett, R. (2015). Social entrepreneurship and value creation in not-for-profit organizations. In Marketing in transition: scarcity, globalism, \& sustainability (pp. 372-376): Springer.

Mulgan, G., Tucker, S., Ali, R., \& Sanders, B. (2007). Social innovation: what it is, why it matters and how it can be accelerated. Skoll Centre for Social Entrepreneurship. London: Young Foundation.

Mulloth, B., Kickul, J. R., \& Gundry, L. K. (2016). Driving technology innovation through social entrepreneurship at Prezi. Journal of Small Business and Enterprise Development, 23(3), 753-767. https://doi.org/10.1108/JSBED-08-2015-0111

Muñoz, P., \& Kimmitt, J. (2019). Social mission as competitive advantage: A configurational analysis of the strategic conditions of social entrepreneurship. Journal of Business Research, 101, 854-861. https://doi.org/10.1016/j.jbusres.2018.11.044

Munshi, N. V. (2010). Value creation, social innovation, and entrepreneurship in global economies. Journal of Asia-Pacific Business, 11(3), 160-165. https://doi.org/10.1080/10599231.2010.500569

Nicholls, A. (2008). Social entrepreneurship: New models of sustainable social change. Oxford: OUP.

Noruzi, M. R., Westover, J. H., \& Rahimi, G. R. (2010). An exploration of social entrepreneurship in the entrepreneurship era. Asian Social Science, 6(6), 3. 
Pennings, J. M. (1975). The relevance of the structural-contingency model for organizational effectiveness. Administrative Science Quarterly, 20(3)393-410. https://doi.org/10.2307/2391999

Peredo, A. M., \& McLean, M. (2006). Social entrepreneurship: A critical review of the concept. Journal of world business, 41(1), 56-65. https://doi.org/10.1016/j.jwb.2005.10.007

Peredo, A. M., McLean, M., \& Tremblay, C. (2019). Indigenous social innovation: what is distinctive? And a research agenda. Handbook of Inclusive Innovation: The Role of Organizations, Markets and Communities in Social Innovation. Cheltenham, UK and Northampton, MA, USA: Edward Elgar Publishing, 107-128.

Phaal, R., Farrukh, C., \& Probert, D. (2001). Technology Roadmapping: linking technology resources to business objectives. University of Cambridge: Centre for Technology Management, 1-18.

Phillips, W., Lee, H., Ghobadian, A., O’Regan, N., \& James, P. (2015). Social innovation and social entrepreneurship: A systematic review. Group \& Organization Management, 40(3), 428-461. https://doi.org/10.1177/1059601114560063

Rawhouser, H., Cummings, M., \& Newbert, S. L. (2019). Social impact measurement: Current approaches and future directions for social entrepreneurship research. Entrepreneurship theory and practice, 43(1), 82-115. https://doi.org/10.1177/1042258717727718

Rey-Martí, A., Ribeiro-Soriano, D., \& Palacios-Marqués, D. (2016). A bibliometric analysis of social entrepreneurship. Journal of Business Research, 69(5), 1651-1655. https://doi.org/10.1016/j.jbusres.2015.10.033

Saebi, T., Foss, N. J., \& Linder, S. (2019). Social entrepreneurship research: Past achievements and future promises. Journal of management, 45(1), 70-95. https://doi.org/10.1177/0149206318793196

Schwab, K. (2008). Global corporate citizenship: working with governments and civil society. Foreign Affairs, 107-118. https://www.jstor.org/stable/20020271

Seelos, C., \& Mair, J. (2005). Social entrepreneurship: Creating new business models to serve the poor. Business horizons, 48(3), 241-246. https://doi.org/10.1016/j.bushor.2004.11.006

Shaw, E., \& de Bruin, A. (2013). Reconsidering capitalism: the promise of social innovation and social entrepreneurship? International Small Business Journal, 31(7), 737-746. https://doi.org/10.1177/0266242613497494

Stevens, R., Moray, N., \& Bruneel, J. (2015). The social and economic mission of social enterprises: Dimensions, measurement, validation, and relation. Entrepreneurship theory and practice, 39(5), 1051-1082. https://doi.org/10.1111/etap.12091

Stevens, R., Moray, N., Bruneel, J., \& Clarysse, B. (2015). Attention allocation to multiple goals: The case of for-profit social enterprises. Strategic management journal, 36(7), 1006-1016. https://doi.org/10.1002/smj.2265

Surie, G. (2017). Creating the innovation ecosystem for renewable energy via social entrepreneurship: Insights from India. Technological Forecasting and Social Change, 121, 184-195. https://doi.org/10.1016/j.techfore.2017.03.006

Turban, E. (2008). Information technology for management: John Wiley \& Sons, Inc.

Van Dalen, H., \& Henkens, K. (2001). What makes a scientific article influential? The case of demographers. Scientometrics, 50(3), 455-482. https://doi.org/10.1023/a:1010510831718

Van Leeuwen, T. (2006). The application of bibliometric analyses in the evaluation of social science research. Who benefits from it, and why it is still feasible. Scientometrics, 66(1), 133-154. https://doi.org/10.1007/s11192-006-0010-7

Volti, R. (2009). Society and Technological Change. New York: Worth.

Wilson, F., \& Post, J. E. (2013). Business models for people, planet (\& profits): exploring the phenomena of social business, a market-based approach to social value creation. Small Business Economics, 40(3), 715-737. https://doi.org/10.1007/s11187-011-9401-0

Wood, D. J. (2010). Measuring corporate social performance: A review. International journal of management reviews, 12(1), 50-84. https://doi.org/10.1111/j.1468-2370.2009.00274.x

Yin, J., \& Chen, H. (2019). Dual-goal management in social enterprises: evidence from China. Management Decision, 57(6), 1362-1381. https://doi.org/10.1108/MD-02-2017-0170 
Yunus, M. (2007). Credit for the poor: Poverty as distant history. Harvard International Review, 29(3), 20-24.

Zadek, S., \& Thake, S. (1997). Practical people, noble causes. London: New Economics Foundation.

Zahra, S. A., Rawhouser, H. N., Bhawe, N., Neubaum, D. O., \& Hayton, J. C. (2008). Globalization of social entrepreneurship opportunities. Strategic entrepreneurship journal, 2(2), 117-131. https://doi.org/10.1002/sej.43

Zahra, S. A., \& Wright, M. (2016). Understanding the social role of entrepreneurship. Journal of Management Studies, 53(4), 610-629. https://doi.org/10.1111/joms.12149

\section{Copyrights}

Copyright for this article is retained by the author(s), with first publication rights granted to the journal.

This is an open-access article distributed under the terms and conditions of the Creative Commons Attribution license (http://creativecommons.org/licenses/by/4.0/). 